\title{
DICTATORSHIP AND THE GERMAN CONSTITUTION: 1933-1937
}

KARI LOEWENSTEIN*

\begin{abstract}
FTER National Socialism had seized power in Germany on January 30, I933, the transformation of the constitutional law of the German Reich was accomplished at an exceedingly rapid rate.
\end{abstract} During the first two years of National Socialist rule there was an enormous output of statutes of basic importance. This rather hectic process of constitutional reconstruction evidently had reached a climax when, on August I, I934, Adolf Hitler united the functions of the Reich President and of the Reich-Chancellor in his person, because the plenitude of absolute power bestowed on the Supreme Leader of the Reich (Reichsführer) was incapable of being further increased. Since then the pace in rebuilding the constitutional structure has ostensibly slackened and it seems safe to state that the outlines of constitutional law as they appear today embody the governmental form of the Third Reich in its final shape.

Among the vast mass of statutes passed during the first four years of National Socialist rule some are considered as of fundamental nature and are spoken of as the basic or organic acts of the Third Reich (Grundgesetz). This official designation, however, does not imply that these acts became integral parts of the fundamental charter (Verfassung im formellen Sinn). Although it has been repeatedly hinted that a completely new constitutional document will be drawn up which would supersede the Weimar Constitution of August II, I9I8, the plan, if ever seriously contemplated, has not as yet materialized. Should a new constitutional charter be adopted, it would scarcely differ much from the constitutional set-up reflected today in the so-called basic acts, ordinary statutes and to a large extent also, in governmental habits or conventions. On the other hand it is open to doubt whether such a formal constitutional instrument will ever be enacted, and this for a very cogent reason. The juridical fixing of a legal order seems irreconcilable with the fundamental principle of a dictatorial system of using new devices to adjust the governmental structure to changing political circumstances. This aim would be frustrated if the virtually boundless jurisdiction of the Supreme Leader were

* Visiting Professor of Political Science, Amherst College; formerly, Lecturer in Constitutional Law at the University of Munich and member of the Munich bar. 
subjected to constitutional limitations inevitable in a written document. Any written constitution, by the very fact of the juridical formulation, creates subjective rights either of the citizens as a whole or of governmental agencies and thus involves a limitation on sovereignty, which in the dictatorial ideology is fundamentally absolute and supreme.

In view of these circumstances it may not be premature to attempt to outline summarily the present constitutional structure of the Third Reich. The survey is confined to the aspects of constitutional law proper as reflected by legislation. It should, however, be borne in mind that even the most scrupulous presentation of the lex scripta never conveys a faithful picture of actual constitutional life unless supplemented by a realistic interpretation and a sociological appraisal of how the statutes operate in practice. No such ambitious scheme can be undertaken in a report which sets out to deal exclusively with constitutional law as revealed by the statute book. ${ }^{x}$

A word may perhaps be added here on the condition of legal science under National Socialism. While constitutional jurisprudence under the Empire and particularly under the Weimar Republic was second to none in originality, legal acumen and awareness of critical values, National Socialist legal science has declined sharply even in purely technical matters. Bent upon the creation of fundamentally new legal concepts, National Socialist constitutional jurisprudence takes pride in pretending that it has established a legal system which is sui generis and beyond the reach of comparative standards. Despite the interpretative and exegetic skill that has been devoted to this end, the system has not shown itself susceptible to analysis even in its own terms. Moreover, National Socialist legal literature lacks the stimulating element attendant on the development of a new administrative technique such as corporativism which has vitalized Italian legal science to such an extent. In describing the German system of constitutional law-notable as it is in many respects - the foreign lawyer who feels himself free from the mystical thraldom of emotional adulation

${ }^{x}$ Although to the author's knowledge no similar purely legal survey of the constitutional situation in Germany has been presented in English, the article makes few references to the vast foreign legal literature of National Socialism. A few of the more important treatments of the subject in English are: Ermath, The New Germany (r936); Marx, Government in the Third Reich (1936); Schumann, The Nazi Dictatorship (1936); Lepawsky, The Nazis Reform the Reich, $3 \circ$ Am. Pol. Sci. Rev. 324 ff. (r936); Wells, The Liquidation of the German Länder, $30 \mathrm{Am}$. Pol. Sci. Rev. 350 (I936). For many collateral points of interest and particularly for bibliographical references see Loewenstein, Law in the Third Reich, 45 Yale L. J. 799 (1936). A searching treatment of the subject, sympathetic to National Socialism, is found in Bonnard, Le droit et l'état dans la doctrine Nationale-Socialiste (1936). The official German doctrine is presented in Neissner-Kaisenberg, Staats- und Verwaltungsrecht im Dritten Reich (I935). 
thus derives little benefit from National Socialist jurisprudence proper, which, by its very nature, is more apologetic than analytic. For obvious reasons the following discussion, although based exclusively on original German sources both in legislation and doctrine, deviates when necessary from the official German interpretation.

\section{THE LEGAL FOUNDATIONS OF THE NEW ORDER}

THE SEIZURE OF POWER

On January 30, 1933, the President of the Reich, von Hindenburg, conferred upon the leader of the National Socialist German Workers Party, Adolf Hitler, the task of forming a new cabinet. The transition of power from the cabinet of von Schleicher to the cabinet of Hitler was in accordance with the actual requirements of the political situation and preserved the legal continuity. It conformed further to the practice of the so-called presidential cabinets lately known under the republic. This type of a plainly perverted parliamentary government stressed more the confidence in the President ${ }^{2}$ than the need of a stable parliamentary backing for the government. ${ }^{3}$ The transformation of parliamentary into presidential government had been possible only by shifting the legislative powers from the Reichstag under the emergency powers of Art. 48.

Obviously this situation could not be continued forever. The political grouping of the electorate made it imperative to form a coalition government, (the government of the National Union) ${ }^{4}$ which was composed of the National Socialist Party and the German National People's Party. In addition, some non-political expert ministers were retained. The key positions, namely the office of the Reich-Chancellor and of the Minister of the Interior, were held by the leading members of the National Socialist Party. 5 The subsequent dissolution of the Reichstag followed the accepted rules of the parliamentary game. The elections held on March 5 , I933, resulted in the following distributions of votes and seats. The National Socialist Party polled $43.9 \%$ of the total votes cast and obtained 288 or $44.5 \%$ of the totality of seats while the corresponding figures for

2 Wiemar Constitution of August II, 19I9, Art. 55 (RGB. I, 1383). RGB signifies the German official law bulletin, Reichsgesetzblatt.

3 Id. at Art. 54.

4 See Ordinance of the Reich President on the dissolution of the Reichstag of February $\mathrm{I}, \mathrm{x}_{933}$ (RGB. I, 45).

$s$ The Minister of War, General von Blomberg, sympathized with the National Socialist Party. Representatives of the German Nationalists were Dr. Hugenberg, von Papen, and Seldte, the latter as representative of the national military organizations. 
the German National People's Party were $8 \%$ of the votes and 52 seats. ${ }^{6}$ Thus the majority obtained by the coalition parties amounted to $52.5 \%$ of all seats and slightly more than the relative majority of all votes cast. In the light of the subsequent events it should be stressed here that the elections from which the National Socialists derived the legal claim to revolutionize the fundamental order of the state yielded only a very slender margin of majority which as it is known was immensely exploited by the victorious parties.

- Moreover, it should be borne in mind that from the viewpoint of the Weimar Constitution then still in force grave objections could be raised against the conduct of the elections themselves. The campaign was no longer under the usual guarantees of freedom of speech, association and assembly which are indispensable to the free expression of popular will. -While the flames of the Reichstag fire were still smouldering, the government, under the pretext of an impending communist rebellion, suspended by ordinance of the President seven of the fundamental rights of the constitution: the right of personal liberty, freedom from arrest, freedom of expression, freedom of assembly, of association and of private property. ${ }^{7}$ These restrictions of the constitutional guarantees told heavily against the democratically minded parties not represented in the coalition, particularly the Social Democrats and the Catholic Center Party. In addition the Court of Inquiry into Elections (Wahlprüfungs-Gericht), ${ }^{8}$ when

${ }^{6}$ The following is a statistical summary of the election:

\begin{tabular}{|c|c|c|c|}
\hline Name of Party & Votes Cast & $\begin{array}{l}\text { Percentage } \\
\text { of Votes }\end{array}$ & $\begin{array}{c}\text { Seats } \\
\text { Obtained }\end{array}$ \\
\hline 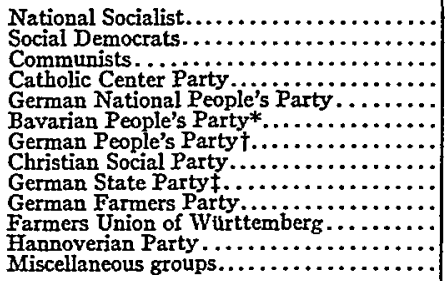 & $\begin{array}{r}17,277,185 \\
7,181,633 \\
4,848,079 \\
4,424,905 \\
3,136,752 \\
1,073,552 \\
432,312 \\
383,969 \\
343,232 \\
1 \pi 4,048 \\
83,893 \\
47,743 \\
5,066\end{array}$ & $\begin{array}{r}43.9 \\
18.3 \\
12.5 \\
11.2 \\
8.0 \\
2.7 \\
1.1 \\
1.0 \\
0.9 \\
0.3 \\
0.2 \\
0.1 \\
0.0\end{array}$ & $\begin{array}{r}288 \\
120 \\
81 \\
73 \\
52 \\
19 \\
2 \\
4 \\
5 \\
2 \\
1 \\
0 \\
0\end{array}$ \\
\hline
\end{tabular}

* The party of the Bavarian Catholics affiliated with the Catholic Center. t The party of big business and heavy industry.

$\ddagger$ The former Democrats, the only genuinely liberal party of the bourgeoisie.

See Pötzsch-Heffter, Vom deutschen Staatsleben (vom 30. Januar bis 3r. Dezember, 1933) 22 Jahrbuch des öffentlichen Rechts 83 (1935).

7 These rights are respectively in Arts. $\mathrm{I}_{4}, \mathrm{Ix}_{5}, \mathrm{II} 7, \mathrm{II} 8, \mathrm{I2}_{3}, \mathrm{I}_{24}, \mathrm{I}_{53}$ of the Weimar Constitution. See Ordinance of the Reich President zum Schutz des deutschen Volkes of February 2, I933 (RGB. I, 35) and Ordinance of the Reich President gegen Verrat am deutschen Volk und gegen hochverräterische Umtriebe of February 28, I933 (RGB. I, 85)

${ }^{8}$ Weimar Constitution, Art. 3 I. 
later called upon to test the validity of the elections was completely controlled by the government and was thus unwilling and incapable of stating authoritatively the validity of the election procedure. ${ }^{9}$ To summarize the election and its results, it is no exaggeration to say that the election which brought National Socialism into power fell considerably short of the standards of freedom of public opinion as guaranteed by the Constitution and it is beyond doubt that without the partisan manipulation by the government the National Socialists and their allies would not have obtained even a relative majority. The constitutional basis on which the reconstruction of Germany on National Socialist lines rests was created mainly by fraud and terrorization.

THE ENABLING ACT AND THE AMENDING POWER

The pivotal point of the constitutional structure of the Third Reich is the act of March 24, I933, "on relief of nation and Reich," the famous "Enabling Act" which is described as the first organic statute of the Third Reich. ${ }^{\mathrm{x}}$ The preamble of the act contains the explicit statement that the vote on the statute "complied with the requirements of legislation amending the Constitution." These words certify authentically that, in conformity with Article 76 of the constitution, a majority of two-thirds of all members were present and that at least two-thirds of those present had voted in favor of the bill..x Beyond doubt the passing of the act through the amending process was indispensable because the Enabling Act, $(\S \mathrm{x})$ involved a process of supplementing the existing constitutional charter with a new type of legislation, the so-called government decrees (Regierungsgesetze) and thus indirectly superseded Articles 68 to 77 of the constitution. ${ }^{12}$ Moreover-and this is in fact the legal key which opened the door for the subsequent reconstruction of the constitutional law- $\$ 2$, sentence I, reads as follows: "The statutes decreed by the government may deviate from the constitution with the reservation that they should not affect the institutions of the Reichstag and of the Federal Council" (italics added). In addition $\S 2$, sentence 2, provides: "The powers of the Reich President are to remain intact." This amazingly simple machinery

- On the basis of his own observations the author entertains substantial doubts as to the correctness of the election procedure in March, I933.

so Gesetz zur Behebung der Not von Volk und Reich of March 24, I933 (RGB. I, I4I).

Ix On the widely ramified and juridically very complex problems of the amending process under the Weimar Constitution, see Loewenstein, Erscheinungsformen der Verfassungsänderung (I93I).

12 This pattern of constitutional amendment was called "constitutional amendment by way of supplement" (Verfassungsergänzung); see $i d$., at II $4 \mathrm{ff}$. 
recommended itself, by contrast to the elaborate cog-wheel system of democratic checks and balances, to people weary of parliamentary complications. By a few printed lines in the statute book the government not only monopolized the regular legislative function but also seized the amending power which the Weimar constitution had reserved to qualified majorities of both houses of the legislature acting together with, under certain conditions, the electorate. The only restriction on the dictatorial exercise of the amending power imposed on the government consisted in the nominal preservation of the "institutional guarantees"13 of the Reichstag and Federal Council as such and the maintenance of the presidential powers. The latter, however, were implicitly curbed by the reservation in the act ${ }^{\mathrm{I} 4}$ which abrogated his rights of participating in the legislative process. Be it noted that the regular type of legislation, that of statutes passed by the Reichstag, was not legally precluded. Subsequently in isolated instances, the Reichstag was convened to pass on acts introduced by the government if their importance from the viewpoint of interior or foreign policy rendered such a formal procedure desirable. On the whole, however, legislation by government decree has become the rule and normal legislation the rare exception. ${ }^{15}$

Since the National Socialist "movement" had officially proclaimed after the abortive putsch of 1923 that power would be sought and gained only by "legal" methods, the juridical doctrine of the Third Reich incessantly stresses the fact that the seizure and exercise of power were wholly

${ }^{\times 3}$ Prior to the Nazi revolution the distinction between guarantee of constitutional rights and "institutional guarantees" by which an institution of the state was protected by the constitution only in so far as its bare existence had to be preserved was much debated by constitutional theorists. In retrospect this discussion indicates the progressive dilution of the bill of rights during the last years of the Republic under the auspices of the versatile Carl Schmitt who served the government of the Republic not less eagerly than the Third Reich. See on the problem of the institutional guarantee, Schmitt, Verfassungslehre I76 (I928); Schmitt, Freiheitsrechte und institutionelle Garantie in der Reichsverfassung, Rechtswissenschaftliche Beiträge zum 25 jährigen Bestehen der Handelshochschule Berlin, $338 \mathrm{ff}$. (I93I), Loewenstein, op. cit. supra note Ir, at 288 ff.; Menzel, Das Ende der institutionellen Garantie, I8 Archiv des öffentlichen Rechts (N.F.) 33 ( 1936 ).

${ }_{4}$ "Arts. 68-77 do not apply to laws decreed by the government." Enabling Act of March 24, I933 § 3. These articles regulate the cooperation of the Reichstag, Federal Council, Reich President and people in the legislative and in the amending process.

Is Not even all "organic" statutes have been submitted to the Reichstag. Thus far only the following acts have been passed by the parliament: Enabling Act of March 24, I933; Reconstruction Act (Gesetz zum Neuaufbau des Reichs of March 30, I934) (RGB. I, 75); the three so-called "Nüremberg laws" (Reichsflaggengesetz; Reichsbürgergesetz, Gesetz zum Schutz des deutschen Bluts und der deutschen Ehre) of September I5, I935 (RGB. I, II45, II46) and finally the act renewing the Enabling Act of January, I937, Gesetz zur Verlängerung des Gesetzes zur Behebung der Not von Volk und Reich of January 30, I937 (RGB. I, I05). 
conformable to the Weimar Constitution, then still in force. It is true that a de facto situation has to be accepted as existing henceforward as being de jure because a successful revolution creates new law. ${ }^{16}$ Thus an intrinsically illegal act is capable of giving birth to a new legal order. Nevertheless, the insistence of the National Socialist doctrine on the "legality" of the seizure of power makes it necessary to investigate this point more closely than it has been possible for legal students to do in the Third Reich.

It is true that an indirect amendment of the constitution, by an amending statute alone, was permissible without incorporating simultaneously or later the alteration intended by the statute in the text of the constitution. This was not explicitly forbidden under the condition that the statute at variance with the text of the constitution was passed by the qualified majorities required for amending acts. ${ }^{{ }^{7} 7}$ The Enabling Act, however, was not only an amendment of one or several clauses of the constitution but it amounted to a complete overthrow of the constitutional order then existing. Such a basic alteration of the entire constitutional structure, a "total revision" in the sense of the French and Swiss jurisprudence, is beyond the jurisdiction of the normal amending organs. It should be submitted to the "original constituent power of the entire German nation." ${ }^{18}$ Although the majority of constitutional lawyers before I933, dismissing this distinction between ordinary and basic alterations of the constitution, ${ }^{19}$ maintained the applicability of Article $76^{20}$ for all amendments whatsoever, it should be noted that the National Socialist party represented only a minority and that even by adding the votes of its partner, the German National People's Party, it remained considerably below the universally accepted minimum requirements for an amending majority.

Another challenge to the constitutionality of the Enabling Act is even more serious. It was passed by a 494-94 vote in the Reichstag, thus conforming formally to Article 76 of the constitution. But 8 r deputies of the outlawed Communist party were illegally barred from attending the meet-

\footnotetext{
${ }^{36}$ See the statement of the Minister of the Reich, Dr. Frick, in the Rules committee of the Reichstag on March 25, 1933; Reichsanzeiger (March 25, 1933).

${ }^{17}$ This method of amending the constitution indirectly had been constantly applied since I9I9, although constitutional lawyers raised strong objection to the laxity of the process; see Loewenstein, Erscheiningsformen $56 \mathrm{ff}$. (I93 I).

${ }^{18}$ Such, at least, was the opinion of Herr Carl Schmitt and his school who were influential before and after the "fall of men" (meaning the light-hearted change of colors of former opponents of the regime) in March, I933; see Schmitt, Verfassungslehre 92 ff., 99, I05 (I928).

19 See Anschütz, Die Verfassung des Deutschen Reichs 403 (4th ed. 1933).

20 Art. 76 of the Weimar Constitution contains the provisions for amendment: two-thirds vote of two-thirds of the Reichstag.
} 
ing and of the I20 members of the Social Democrats only 94 were admitted. ${ }^{2 x}$ In addition, 92 members of the Catholic Center, the Social Democrats, and minor "splinter parties" voting for the act were prevented from giving a free and unbiased vote. The mob unleashed by the government ruled the capitol and the vote was taken in an indescribable atmosphere of terrorization and coercion.

The final point bearing essentially on the constitutionality of future legislation on the basis of the Enabling Act is the most important. The act declared in Article 5: "Furthermore this act ceases to be effective when the present government of the Reich is replaced by another one." On June 29, I933, Dr. Hugenberg, Minister of Nutrition and Agriculture, resigned from the cabinet under pressure. By the withdrawal of the foremost representative of the German National People's Party the very nature of the coalition government was destroyed because only by support of the German Nationals had the National Socialists attained the relative majority of votes and seats. It can be argued that the cabinet of Hitler, after the resignation of the coalition partner preserved its formal identity and that no new cabinet was summoned; yet the crux of the situation was not different from that under the Enabling Act of $1923 .{ }^{22}$ The powers of the Enabling Act were accorded to a coalition government which as such had received the parliamentary mandate. After the resignation of the German Nationals, followed immediately by the suppression of the party itself, the political identity of the cabinet was fundamentally changed. By no stretch of imagination could it be maintained that the sweeping powers of the act would have been given to the National Socialists alone because the presence of the German Nationals in the government was considered by all parties voting for the act as a sort of political brake. Thus the act lost its political basis and thereby also its legal justification. ${ }^{23}$

It is not beside the point to stress here these constitutional aspects of the situation because, if the Enabling Act itself is invalid, every single

${ }^{2}$ Most of the deputies excluded were in hiding, in exile, in concentration camps, or assassinated.

22 The Enabling Act of October Io, I923 (RGB. I, 943) was to expire if and when "a change occurs in the present Reich government or in the parties of which it is at present composed." After the Social Democrats had resigned from the coalition the act became automatically invalid. The formulation in I923 differed from that in I 933 in so far as the act of I933 lapses "if the present Reich government is replaced by another one" while the act of $x 923$ was to expire when the coalition broke, but in both cases the implied meaning was the same. Thus the I923 act would seem to provide a pertinent precedent for the subsequent invalidity of the I933 act.

${ }^{23}$ Needless to say nobody within Germany dared to allude to this fact nor did it find adequate attention of the constitutional lawyers outside of the jurisdiction of the Third Reich. 
step of the subsequent revolution on the basis of the Enabling Act leads into a legal no-man's-land. ${ }^{24}$ While it may be correct to say that no revolutionary government is to be subjected to the legal standards of the order which it has overthrown, it must be clearly understood that even a revolutionary government is bound by the legal standards established by it as guidance for future actions. Otherwise it forfeits the title of a constitutional government of its own right-a title which the National Socialists are so anxious to claim. ${ }^{25}$

On November I2, I933, a new Reichstag was elected which, besides a few non-party members appointed on the National Socialist ticket, contained only party representatives of the National Socialists, the only political party legally recognized since July, I933. By the Reconstruction Act of January 30 , I934, which is also an organic act, ${ }^{26}$ the Reichstag conferred unanimously upon the cabinet the pouvoir constituant without any limitations, thus demolishing the last residues of constitutional guarantees of the Enabling Act. Article 4 declares in unequivocal terms: "The government of the Reich may enact new constitutional law." Henceforward, the amending process became identical with the ordinary legislative procedure, both being exercised by simple government decree.

THE VALIDITY OF THE WEIMAR CONSTITUTION

The Constitution of Weimar was never formally repealed. This would happen only if a new fundamental charter were enacted. Since the government may, by simple decree, establish new constitutional law, those institutions of the Third Reich which are in conflict with the Weimar constitution are valid only in conformity with the principle of lex posterior derogat legi priori. ${ }^{27}$ Occasionally institutions of the Weimar Charter were

24 This argument affects particularly the constitutionality of the act concerning the prohibition of political parties of July I4, I933 (RGB. I, 479) by which the preceding dissolution of the other political parties was legalized. The Communist party was proscribed immediately after the elections of March 5, I933. The Social Democratic party was prohibited at the end of June, r933, by the governments of the Länder on instructions of the Reich Minister of the Interior. This procedure had not even the pretext of legality and was accomplished only by terror or actual violence. The bourgeois parties preferred political suicide by "self-effacement" under the coercion of the SA, the storm troopers, and the Political Police. All parties were wiped out within one week (June 26 to July 5, 1933). Similarly the elections of November 12, I933, and the Reconstruction Act of January 30, I934 (RGB. I, 75) are devoid of constitutionality.

${ }^{25}$ See Loewenstein, Law in the Third Reich, 45 Yale L. J. 779, 812 ff., notes I2I-24 (I936).

${ }^{26}$ Gesetz über den Neuaufbau des Reichs of January 30, r934 (RGB. I, 75).

${ }^{27}$ Technically the pattern of constitutional amendment which consists in enacting new provisions without formally repealing the older ones is spoken of as "constitutional amendment by way of dislodgment" (Verfassungsverdrängung); see Loewenstein, Erscheinungsformen $\mathrm{II}_{3} \mathrm{ff}$., I $_{49} \mathrm{ff}$. ( I93 $^{\mathrm{r}}$ ). 
formally abolished-such as the Federal Council and the Reich Economic Council in x934. In other instances provisions of the former charter, while generally maintained, were subjected to restrictions or exemptions, ${ }^{28}$ according to the principle of lex specialis derogat legi generali. 29 More frequently, however, the new constitutional law may be characterized as having informally overruled older provisions which were deemed incompatible with the National Socialist postulate of the supremacy of the totalitarian leadership state. Instead of explicit judicial or governmental act the mere assumption that a former provision conflicts with the new system of law suffices. This vagueness entails considerable difficulties for the courts in applying the law. After some significant vacillations the National Socialist doctrine reverted to the principle that the judge is subject to the law. But in view of the manifest contradictions between the old and the new fundamental principles, what exactly is the law? A broad rule of interpretation is supposed to solve the problem. The judge is to decide according to judicial discretion and conscience whether a statutory provision not yet repealed is in conflict with the spirit of the new order. Evidently no doubt arises as to rules of law passed since the seizure of power. The new law as the binding expression of the Leader's will claims precedence of right over all other rules of law even if contained in the former constitution. Concerning the rules passed prior to the $\mathrm{Na}$ tional Socialist revolution the judge is bound only by his conception of the National Socialist "spirit." The altogether unique and paradoxical situation exists that the new National Socialist law overrides not only former ordinary law but also former fundamental law. Thus the bulk of the Constitution of Weimar is "de-constitutionalized."30 This implies that parts of the Weimar Constitution continued to be in force although deprived of their formal character and subject to being amended at any time by governmental decree, government ordinance and statutes passed by the Reichstag. Whatever the reference to the National Socialist "spirit" may mean, the obvious result is constitutional chaos in the place of a clear-cut hierarchy between organic and ordinary law.

Particular difficulties arose in connection with the Bill of Rights of the second part of the constitution. The most important among them ${ }^{3 \mathrm{x}}$ were

${ }^{28}$ This pattern of constitutional amendment is spoken of as "perforation" of the constitution (Verfassungsdurchbrechung); see Loewenstein, Erscheinungsformen I64 ff., $233 \mathrm{ff}$. (r93I).

${ }_{29}$ The numerous violations of Art. Iog (guaranteeing equality before the law), in dismissing public officials for "political unreliability," or the exclusion of the Jews from the civil service and the professions, and depriving them of political rights, are illustrations.

${ }^{30}$ See Loewenstein, Law in the Third Reich, 45 Yale L. J. 779, 802 ff. (I936).

${ }^{3 r}$ See note 7 supra. 
suspended on the basis of Article 48 by ordinance of the President of February 28, I933. This temporary expedient has never been repealed although the regime has stabilized itself in the meantime. But most of the other guaranteed rights are equally outlawed, such as the principle of equality ${ }^{32}$ and the well established principle of nulla poena sine lege. ${ }^{33}$ The act on the prohibition of political parties ${ }^{34}$ suppressed the freedom of assembly, of association and of public opinion. ${ }^{35}$ Space forbids giving a detailed description of how the second part of the constitution was scrapped..$^{36}$ Violations of the right of private property and of the guarantee of vested rights-a legal term which in Germany has no political connotation as in this country-were so frequent that at present they pass unnoticed. ${ }^{37}$

In brief, the Constitution of Weimar though not formally repealed has been materially abrogated. The constitutional lawyer should no longer evaluate the new revolutionary order in terms of a constitutional system

${ }^{32}$ Art, rog. The concept of equality is particularly obnoxious to the National Socialist doctrine which extols the values of the "elite" and of the "leaders" as against what is called the "soulless mechanization of democratic equality."

33 Art. I16. This principle, unconditionally recognized by all civilized nations-was officially abolished by the act of June 28 , I935 (RGB. I, 839) concerning additions to the penal code. Conviction of the accused "by way of analogy" was introduced, which allows punishment although the actual facts of the case may not justify it. In addition punishment without previous determination of the crime was made compulsory by the standards of what has been called "the sound consciousness of the people" as interpreted arbitrarily by the judge.

34 See note 24 sitpra.

${ }_{35}$ The right of the freedom of opinion was officially denied by the Editors Act (Schriftleitergesetz) of October 4, I933 (RGB. I, 7I3) by which the exercise of the journalistic profession is made dependent on political conformity.

${ }^{36}$ One of the very few constitutional controversies which the courts were permitted to indulge in arose in connection with Art. 137 of the constitution which guarantees the freedom of association for religious purposes. Several of the less coordinated higher courts insisted that this article, because not conflicting with the National Socialist principles, was not implicitly abolished and that therefore the religious sect of the "Ernste Bibelforscher" (similar to the "Children of Jehovah" who refused to salute the flag in this country) should be permitted to continue. The problem was solved by declaring them Communists. On the legal controversy, see Pötzsch-Heffter, Vom deutschen Staatsleben (vom 30. Januar bis 3r. Dezember, 1933), 22 Jahrbuch des öffentlichen Rechts 2I0 ff. (I935); Stödter, Verfassungsproblematik und Rechtspraxis, 27 Archiv des öffentlichen Rechts (N.F.) I66 ff. (1936). See further the decisions of the Supreme Court (Reichsgericht), Juristische Wochenschrift 767, 2070 (1934); Oberlandesgericht Darmstadt, Juristische Wochenschrift I774; Sondergericht Breslau, Deutsche Richter zeitung no. 432 (r935); Hanseatisches Sondergericht (City of Hamburg), 57 Reichsverwaltungsblatt 700 (I935).

${ }^{37}$ The author is preparing a study on the position of private property in the Third Reich which demonstrates, on the basis of official documentation, that the confiscatory trend of totalitarian legislation and of the practice under the Four Years Plan comes very close to the system of restricted property under Bolshevism. 
which, by the force of revolutionary logic, has passed from actual law into history.

\section{THE FEDERAI STRUCTURE IN REICH AND LÄNDER ${ }^{38}$}

THE TRANSFORALATION OF THE FEDERAL STATE INTO THE UNITARY STATE

Besides the substitution of the monocratic single party state for the multiple parliamentary state, by far the most conspicuous development in Germany since 1933 consists in the transformation of the federal into the unitary and centralized state. Objectively seen this change represents that achievement of the regime which is most likely to be permanent. Beyond doubt, the administrative unification of the Reich was delayed by the intrinsic laws of German history. Even the Weimar Constitution offered little more than a hesitant and transitional solution. The political trend of our age is certainly toward centralization. Grave doubt, however, exists as to whether the sociological stratification of the German people justifies the headlong plunge into rigid centralization which deliberately neglects religious diversities and the tribal peculiarities of the country. The cultural multiformity, perhaps the most attractive result of historical development, was scratched out by a stroke of the legislative pen. Rigid centralization, however, meets the necessities of dictatorship, which is bound to dominate the territory without intermediary institutions. Thus political coordination between Reich and Länder promoted the political aims of the government which, by coercion, could overcome successfully the historical and sentimental residues of federalism.

The transformation was accomplished within less than one year. ${ }^{39}$ The first preliminary act for "co-ordinating the Reich and Länder" of March, I933 ${ }^{40}$ was aimed mainly at leveling down the existing political differences within the various states. On the basis of the second act for coordinating the Länder with the Reich of April, I933, ${ }^{4 \mathbf{x}}$ Reich-Regents (Reichs-Statthalter) were appointed by the Reich President, on advice of the ReichChancellor. ${ }^{42}$ The task of the Regents was that of enforcing the political

${ }^{38}$ The Länder are the states of Germany, such as Prussia.

${ }^{39}$ See Wells, Liquidation of the German Länder, 30 Am. Pol. Sci. Rev. 350 (I936) for an excellent discussion.

40 Vorläufiges Gesetz zur Gleichschaltung der Länder mit dem Reich of March 3I, I933 (RGB. I, I53).

45 Second Gesetz zur Gleichschaltung der Länder mit dem Reich of April, 7 I933 § 2 (RGB. I, I73) with alterations of April 25, 1933 (RGB. I, 225), May 26, I933 (RGB. I, 293) and October I4, I933 (RGB. I, 736).

42 Reich-Regents govern at present the following eleven Länder: Bavaria, Württemberg, Baden, Saxony, Thuringia, Hesse, Hamburg, the two Mecklenburgs (now united into one administrative unit; until I937 the Regent for the Mecklenburgs was also Regent for Lübeck), 
instructions of the Reich Chancellor. ${ }^{43}$ On the whole they functioned as a sort of state president appointed by the Reich. While removed from local politics, the Regents were authorized to appoint and dismiss the state governments, to dissolve the local parliaments and to appoint the local officials. Only for Prussia did the Reich Chancellor reserve to himself the powers of the Prussian Regent and simultaneously delegated them to the Prussian Prime Minister. ${ }^{44}$ Thus the institution of the Reich-Regents guaranteed political unity within the states and political conformity with the Reich because the Regents as subordinates of the Supreme Leader represented the interests of the Reich and not of the Länder. Prussia, by the personal union of the offices of the Reich Chancellor and of the Prussian Regent, became a sort of jurisdictional province of the Reich.

In spite of these changes the dualism between the Länder and the Reich which was among the main causes of the downfall of the Republic was by no means overcome permanently. In fact, the federalistic spirit of resistance was so deeply rooted, that the Länder preserved a considerable degree of individuality as political units. The influence of a nationally homogeneous party helped little in suppressing federalistic tendencies, nor did the Regents, as is illustrated by the attitude of the Bavarian National Socialists who were pursuing decidedly Bavarian interests. Thus the complete elimination of the Länder as quasi-independent political entities became inevitable lest the traditional federalism would transcend the frame of the single party state. This huge step was taken in the Reconstruction Act of January 30 , I934, ${ }^{45}$ the second organic act of the Third Reich. The sovereign powers of the states were transferred to the Reich while the governments of the states were reduced to agencies of the Reich government. The Regents were subordinated to the Reich Minister of the Interior. The result is that at present the Reich for all intents and purposes is a unitary state and that the Länder are only provincial units administered by the Reich. The governments of the states are converted into bureaus of the Reich, the officials of the Länder are henceforward officials of the Reich and almost all powers of the Länder were transferred to the central authorities.

The plan of a regional subdivision of the Reich on geographical or rath-

Oldenburg and Bremen, Brunswick and Anhalt, and the two Lippes. These territories are very unequal in size and population and still reflect the traditional dynastic boundaries of the German states.

${ }^{43}$ Act of April 7, I933 § I. See note 4I supra.

44 Edict (Erlass) of the Reich Chancellor of April 23, I933 (RGB. I, 226).

15 Gesetz zum Neuaufbau des Reichs of January 30, I934 (RGB. I, 75). 
er economic lines, much debated and until now beset by insuperable obstacles, has not yet materialized. Only the Länder of MecklenburgStrelitz and of Mecklenburg-Schwerin have been merged into one Land Mecklenburg. ${ }^{46}$ Minor rectifications of the state lines by exchanging territories between the Länder of Prussia, Hamburg and Oldenburg were accomplished in the so-called "little Reich reform" of 1937 by which also the time-honored Free City of Lübeck was wiped from the map and its territory distributed among the neighboring Länder. ${ }^{47}$ Any major reconstruction of the territories of the Länder on what is called rational or economic lines seems, at least for the time being, impossible, perhaps because of the underground resistance of local interests. Yet an attempt was made to breaks down the stubborn homogeneous state consciousness of Prussia by making the governors of the Prussian provinces (Oberpräsidenten) the immediate and personal agents of the Reich government.

Finally political friction arising from the fact that the Regent was personally subject to the orders of the Reich Chancellor but beyond the jurisdiction of the Minister of the Interior was removed by the Reich Regents Act of January 30 , I935, ${ }^{48}$ the third of the organic acts. The Regent became a subordinate of the Reich Minister of the Interior and thus was incorporated into the Reich administration as a normal organ. On the whole, this move was equivalent to a capitis deminutio of the Regents. Although nominally not officials of the Reich, ${ }^{49}$ they are political organs of

${ }^{6} \mathrm{Gesetz}$ über die Vereinigung von Mecklenburg-Strelitz mit Mecklenburg-Schwerin of December I6, I933 (RGB. I, I065). The position of the Saar after the return to Germany was revised by the Gesetz über die vorläufige Verwaltung des Saarlandes of January 30, I935 (RGB.I, 68). The re-incorporation of the Saar into the Reich after seventeen years of separation in which the social structure of the Reich had been completely changed offered legislative and administrative problems of the first magnitude. The accomplishment of the task shows the ministerial bureaucracy at its best.

${ }_{47}$ Gesetz über Grosshamburg und andere Gebietsvereinigungen of January 26, 1937 (RGB. I, 9r). For a long time the densely populated district around Hamburg badly needed a territorial realignment because parts of the area of the city of Hamburg belonged administratively to three different states. The act organizes a "Land" Hamburg (the Hansestadt Hamburg), the territory of which was considerably increased. No better illustration of the subordinate political position of the Länder can be found than in the provision in Art. I, $\$ 4$ of the act: "Constitution and administration of the Land Hamburg and of the Hanse-City of Hamburg regulated by the Reich-Minister of the Interior in consultation with the DeputyLeader." Thus not even the Reich Regent of Hamburg participates in the establishment of the fundamental order of the Land.

$4^{8}$ Reichsstatthaltergesetz of January 30, I935 (RGB. I, 65).

49 Until the enactment of the new Public Officials Act of January 26, 1937 (RGB. I, 39) the Regents were under the Reich-Minister Act of February 27, r93० (RGB. I, 96) and the act of June 30, I933 C. 6 (RGB. I, 433). The Public Officials Act of 1937 I84, however, re- 
the Reich subject to direct orders of the Reich government. In their present status they function as intermediary agencies between the central and the local administrations, but their political power and actual sphere of influence is very limited, in fact they are more a sort of a buffer between the provinces and the capital than a center of independent action.

The solution ultimately found seems logical and satisfies the end of maintaining the essential unity of political command while allowing for a certain elasticity of local enforcement. On the other hand the consciousness of statehood which in the past has been one of the cornerstones of German politics is submerged for the time being. It remains to be seen whether or not a resurrection takes place whenever the pressure of the one party state relaxes.

As to the relation of the Reich legislation to the legislation of the Länder, the Reconstruction Act of 1934 disposed of the independent legislative powers of the Länder by monopolizing the legislative jurisdiction in the hands of the Reich. Actually, however, the authorities of the Länder exercise, by delegation from the Reich, the legislative power in purely local matters. Control of the Reich is provided for by the fact that local statutes may be enacted only by explicit consent of the Reich minister to whose department the matter belongs. ${ }^{50}$ In conformity with the suppression of the Länder, uniform Reich legislation spread rapidly over all fields previously reserved to the states. This process, perhaps the most beneficial of all steps undertaken by National Socialism, is called "Verreichlichung." Since it is impossible to enumerate all such uniform statutes only a few of the more important fields are mentioned here: civil service, trade and crafts, press, administration of justice, taxes, traffic, local government, police and even most of the cultural activities.

THE ORGANIZATION OF THE LÄNDER

It is misleading, however, to assume that Germany is at present a homogeneous and uniform country like France or Italy. It would be more appropriate to liken the present status of the Länder to that of Scotland or Wales within the frame of the United Kingdom. The situation may be summarized as follows: since progressively more functions of the Länder were transferred to the Reich, the independent governments of the Länder were more and more "hollowed out." Gradually the political

pealed most of the Reich-Minister Act of 1930 by incorporating many of the provisions of the older act. The author was unable to verify whether or not this act changed the position of the Reich Regents.

so First Ordinance concerning the reconstruction of the Reich of February 2, 1934, $\S \S$ I, 3 (RGB. I, 84). 
institutions of the Länder were thrown on the dust heap. First to disappear were the Länder diets. ${ }^{5 x}$ The powers of the suppressed parliaments, insofar as they survived were usurped by the Länder governments, a process which reflects faithfully the identical development within the Reich. ${ }^{52}$ As a final solution the Reconstruction Act of I934 not only abolished the parliaments of the Länder altogether, but transferred also, as a consequence of the disappearance of the legislative powers of the Länder, the Länder governments into agencies of the Reich exercising powers delegated by the Reich. What little of legislative functions is still left to the Länder is thus only re-delegated on trust from the Reich to the Länder. ${ }^{53}$ If the Reich prefers to have a statute passed which applies only to the territory of the former Land, the government of the Land may do so by and with the consent of the Reich Minister to whose jurisdiction the matter belongs. While nominally such an act bears the signature of the government of the Land it is actually an act of the Reich. It is not clear why this indirect method of federal legislation was established. It would be more logical if the Reich government legislated on Prussia or Bavaria directly, as Congress legislates for the District of Columbia or the British parliament for Scotland or Wales.

In view of the fundamental change in the federal structure the Federal Council (Reichsrat), hitherto the organ of the collective will of the Länder, was abolished. ${ }^{54}$ The final solution brought the Reich Regents

sx The (First) Act for the coordination of the Länder with the Reich of March 3r, I933 (RGB. I, I53) provided for a re-appointment, not re-election, of the diets in conformity with the results of the Reichstag elections of March 5, I933. Only the Prussian parliament was excepted which had been elected simultaneously with the Reichstag on March 5, I933. Sec. II of the act decreed the automatic dissolution of the Länder-diets when the Reichstag was subsequently to be dissolved. Be it noted that the independent elections for the Länder-parliaments during the Republican period had served the same useful purpose achieved by "byelections" for the British parliament in indicating the trend of public opinion. The Nazi strategy had concentrated the whole strength of the powerful machine on such local elections in order to impress its irresistibility on the public, especially in such states where the movement had less support. By telegram (sic) of Nov. I6, I933, the Minister of the Interior instructed the Regents to forego new elections for the Länder-diets. See Pötzsch-Heffter, Vom deutschen Staatsleben (vom. 30. Januar bis 3 r. Dezember 1933), 22 Jahrbuch des öffentlichen Rechts ${ }_{53}$ (I935). Thus the Länder-parliaments ceased to exist.

52 By $\S$ I of the Coordination Act, see note 40 supra, the state government was empowered to enact rules of law by government decree overruling the powers of the parliaments proper. A simple government decree could pass the budget and even amend the constitutional charter of the Land.

53 See the important First Ordinance concerning the reconstruction of the Reich of February 2, I934, § I (RGB. I, 8I).

54 Gesetz über die Aufhebung des Reichsrats of February I4, I934 (RGB. I, 89). Similarly the Reich Economic Council (Reichswirtschaftsrat), at first reorganized (see act of April 5, I933 (RGB. I, I65)), was abolished by act of March 23, I934 (RGB. II, II5). 
Act of January 30 , I935, ${ }^{55}$ which eliminated the last remnants of the separate governments of the Länder. The Führer and Reich Chancellor may intrust to the Reich Regent the actual conduct of the government within the Land. Ministers of the Länder wherever they survive are appointed and dismissed by the Führer, on suggestion of the Regent. The Regent promulgates the statutes of the Länder after having obtained the consent of the Reich cabinet.

It is significant that in spite of the uniformity intended by the Reich Regent Act the actual situation varies still in the various Länder. In Bavaria a Prime Minister and a government exist besides the Regent, ${ }^{56}$ while in Saxony and Hesse the offices of Regent and of Prime Minister are merged in the person of the former. ${ }^{57}$ In Prussia the situation is again different. The Führer and Reich Chancellor holds nominally the office of the Regent, but actually, by delegation, the functions are exercised by the Prussian Minister President. The members of the Reich cabinet are exofficio members of the Prussian cabinet with the exception of the Minister of Finance of the Reich, becausePrussia still retains her own Ministry of Finance. In order to avoid duplication in staff and administration all other originally separate departments of Prussia were in due course absorbed by the corresponding Reich ministries. Thus the Prussian government is an integral part of the Reich government and conversely. This solution of the dualism between the Reich and its largest member state, Prussia, is strikingly similar to the constitutional settlement under the Bismarck constitution of $187 \mathrm{I}$, a fact which once more indicates the law of inertia governing structural change.

In this connection, mention should be made of a new institution, namely the so-called Council of State in Prussia established for advising the state government, ${ }^{8}$ which is a rather superfluous imitation of the Italian Gran Consiglio of the Fascist party. All the highest party officials were appointed to it by the Minister President, in addition to representatives of the church, economic life, labor, science and art, and "other men of merit in the state and nation." Membership is for life but dependent on the tenure of the party office. The Council of State is merely decorative.

s5 Reichsstatthaltergesetz of January 30, I935, $\$ \$ 4,5$ (RGB. I, 65).

${ }^{56}$ In Bavaria the district party leaders (Gauleiter) hold at the same time the office of the head of the state district administration (Kreisregierung). They are ex-officio members of the Bavaria cabinet (without portfolio).

57 Edict of the Reich Chancellor of February 28, I935.

${ }^{8}$ Prussian Law of July 8, I933, Gesetzessammlung 24I. Hamburg has a similar advisory institution. 
While no political importance whatsoever is attached to it, it is a conspicuous instrument of legalized party patronage. 59

\section{THE GOVERNMENT OF THE REICH (REICHSFÜHRUNG)}

THE HEAD OF THE STATE: THE FÜHRER AND REICH CHANCELIOR

The essence of the political revolution in Germany may be expressed adequately by the simple statement that the will of one man alone, the Fuihrer, is sovereign, free from any constitutional limitations whatsoever. This unequivocal fact, however, is embedded in involved terms of constitutional law, evidently because the prejudices and habits of the German people cling stubbornly to the legalistic mummery by which arbitrariness is disguised. Psychological rather than technical considerations are responsible for the preservation of the traditional forms of constitutional law. While every pattern of constitutional government is necessarily complicated and difficult in operation because of the cooperation of various organs, the dictatorship of the Third Reich is an exceedingly simple, intelligible and logical mechanism. During the lifetime of Reich President von Hindenburg, the dualism between the Reich-presidency and the office of the Führer and Reich Chancellor had to be maintained for symbolic reasons although the Reich President had been denuded of most of his powers. ${ }^{60}$ The reservation of the Enabling Act that "the powers of the Reich President are to remain untouched" was practically meaningless because the functions of the President in connection with the legislative

59 According to $\S \mathrm{I} 4$ of the Law on the Council of State, the office of the Councillor of State is an honorary one with which, in addition to the gratuitous use of all state railroads, a salary is connected. The monthly remuneration amounts to roo marks for members residing outside of Berlin and to 500 marks for those who are residents of the capital. Executory Ordinance of July 7, I933, Gesetzsammlung 265. All members of the Council of State are wealthy men or derive income from other state or party offices. Yet the law explicitly forbids renunciation of the salary, a pertinent illustration of the official slogan that "commonweal takes precedence over private weal."

60 The "Old Man" was already during the last years of the Republic a deliberately built-up legend for which the government of Dr. Brïning is much more responsible than the National Socialists who, when still in opposition, did not shy away from violent attacks upon his person. It fits well into the picture of political corruption accompanying the transition from the Republic to the single party state of the National Socialists that he who, by virtue of his oath, was to be "the custodian of the constitution," as Herr Carl Schmitt and others emphasized, became the official "protector of the Third Reich" immediately after the wirepullers of the "national revolution" had persuaded him to change his colors. As substantial reward for his historical mission he accepted from the Reich the gift of the large estate of Langenau "rounding off" the family estate of Neudeck. By the act of July 27, I933 (RGB. I, 595) the estate of Neudeck thus enlarged was exempted from all taxes "during tenure by a male member of the family of von Hindenburg." The statute book reveals discreetly the important role played by the male heir, Herr Oskar von Hindenburg. 
process were overridden by the practice of government decrees. The personal confidence of the President in the Chancellor was, in view of the revolutionary pressure of the mobilized party, a mere fiction. Still important, however, was the fact that the President was constitutionally the commander-in-chief of the armed forces, the Reichswehr. ${ }^{6 \mathbf{x}}$

The latent conflict was solved, after the death of von Hindenburg on August I, I934, by the act concerning the head of the state, the Succession Act, another organic statute of the Third Reich. ${ }^{62}$ The offices of President and Chancellor were merged into one, and the powers of the President were transferred to the Führer and Chancellor. Thus finally the statute book reflected what already existed in reality, namely, the unlimited sovereignty of the Führer within the German realm. The official title of Hitler is now that of "Führer und Reichskanzler." ${ }_{3}$

At present the powers of the Führer and Reich-Chancellor may be grouped along the following lines. First, he exercises all powers which still belong to the President according to the Weimar Constitution, including the supreme command of the armed forces, ${ }^{64}$ power to dissolve the Reichstag, to appoint and dismiss the Reich ministers and the public offcials, the privilege of mercy-which, under the Third Reich, was extended to the discretionary power of quashing pending criminal proceedings,and functions of representing the Reich internationally, and of remodelling the governmental departments (Organisationshoheit). In the second place he has a new series of powers, derived from the organic acts of the regime such as the powers of appointment and dismissal of the Reich Regents, the ministers, the officials of the Länder, and power to appoint the Deputy-Leader. ${ }^{65}$ Finally, the Fuihrer is endowed with those powers which spring from the National Socialist mythology. By their very nature they are incapable of being integrated by the lex scripta. Although

6x When the Führer rid himself of the allegedly restive leaders of the party army, the SA, by the ominous blood purge of June $30, \mathrm{r}_{934}$, he anticipated the consequences of the imminent death of the Reich President, August r, r934. See on this subject Loewenstein, Autocracy versus Democracy in Contemporary Europe, $29 \mathrm{Am}$. Pol. Sci. Rev. 589 (1935). Thus Hitler was relieved from making a choice between the two rival bodies of the regular and of the revolutionary party army and was able to enlist at once the wholehearted support of the Reichswehr, which the blood purge restored to its undisputed military monopoly.

${ }_{62}^{6}$ Gesetz über das Staatsoberhaupt des deutschen Reichs of August 2, x934 (RGB. I, 747).

${ }^{6} 3$ The bureau of the Reich President, the presidential Chancellery (Reichskanzlei), remained unchanged.

64 Even the imperial title of "Supreme War Lord" (Oberster Kriegsherr) was, at least unofficially, restored.

${ }_{6}$ This right is not yet exercised. Hess acts as Deputy-Leader only in respect to the party. It is more likely than not that Göring one day will be promoted to the title and office of the Deputy-Führer of the entire state. 
they defy adequate translation they may be characterized as follows: the Fuihrer is the "bearer of the legal will of the racial community" as well as the bearer of the ultimate responsibility as "addressee of the duty of fealty" (Treupflicht). All ministers, officials, Regents and members of the armed forces are responsible to him alone. "All powers are concentrated in his person while he himself is responsible only to the nation." these mystical and symbolic powers are better translated into terms of theology than of law and while they have the most tangible reality for the time being, they can be evaluated only by the judgment of history. In view of the fait accompli the plebiscite taken on the merger of the offices on August 19, r934, was significant only as a declaratory statement.

In conformity with the new notion of responsibility in the "leadershipstate" the traditional duties incumbent on all kinds of officeholders are converted into the ethical concepts of fealty similar to those governing the feudal relationship between the lord and his retainers (Treueverhältnis zwischen Führer und Gefolgschaft). The official doctrine of National Socialism emphasizes this irrational and mystical mutuality of support and protection, of confidence and responsibility as a fundamental element of the new constitutional order. Outwardly the new concept of loyalty is reflected in the oath of allegiance to be sworn by all persons holding office in party and state to the Führer. ${ }^{67}$ The solemn obligation is not given to the abstract entity of the state but to the human person of the Führer himself.

\section{THE CABINET (REICHSREGIERUNG)}

Under the Weimar Republic, the Reich government was a rather complicated blend of a parliamentary cabinet, acting in collective capacity, and the Bismarckian "chancellor principle" which operated on the assumption of the monocratic responsibility of the chancellor. Furthermore, under the Republic the constitutional position of the government was obfuscated by the contradiction that it was dependent on the confdence of both the President and of the Reichstag. This much deplored constitutional ambiguity led to the practice of presidential cabinets which became inevitable when the strong radical parties on the right and the left wing refused to lend themselves to parliamentary collaboration.

${ }^{66}$ The Minister of the Reich, Dr. Frick, in a conference of the press held on January 9, x935, see Meissner-Kaisenberg, Staats- und Verwaltungsrecht im Dritten Reich 49 (I935).

${ }^{67}$ Gesetz über die Beeidigung der Beamten und der Soldaten der Wehrmacht of August 20, I934 (RGB. I, 785); Gesetz über den Eid der Reichsminister und der Mitglieder der Landesregierungen of October x6, r934 (RGB. I, 973); Public Officials Act of January 26, 1937, \$ 4 (RGB.I, 39): "I shall be faithful and obedient to the Führer of the German Reich and Nation, Adolf Fitler, and I shall fulfil conscientiously the duties of a public official, of which the Lord be my witness." 
During a short period after the advent of the National Socialists to power, the character of collective solidarity within the cabinet was preserved, at least as a fiction. After the German Nationalists were thrown out of the cabinet the leadership-principle was substituted for the power of the Chancellor of determining, as primus inter pares, the general policy of the government (Richtlinienbestimmungsrecht). The Succession Act of 1934 officially confirmed the actual practice. Now the members of the cabinet obey the command of the leader (Führerbefehl) binding upon all. Thus the individual minister is subjected to the discretionary interference of the Führer even within his own department. ${ }^{68}$ The leadershipprinciple precludes votes among the members of the cabinet; the individual minister conducts the business of his department alone, subject to instructions of the Chancellor, who also straightens out differences of opinion among the ministers. ${ }^{69}$ Important decisions of the ministers as heads of the departments need also the consent of the ministers of Finance and of the Interior and in addition the Deputy-Leader may veto them. On the whole the individual ministers are more independent than under the former collective system..$^{70}$ Ministers without portfolio may be admitted to the cabinet. ${ }^{7 x}$ The legal position of the ministers, at first regulated by the former Ministers Act of 1930 , was recently restated by the Public Officials Act of $19377^{72}$

${ }^{68}$ The Standing Orders of the Reich government (Geschäftsordnung) of May 23, r924, and April I4, I926 (RGB. (I924) I, I73, id. (1926)I, 3I9), one of the most remarkable constitutional documents of the republic, were not repealed but adjusted.

${ }^{69}$ Evidently decisions taken by the whole cabinet after oral discussion are rather an exception. It seems that as a rule decisions are taken by way of signatures attached to the minutes circulating among the members of the cabinet. It may be that the frequent absences of the Führer from the capital, to which he allegedly prefers his estate at Berchtesgaden, have contributed to this development. Berchtesgaden is on the way toward becoming a second capital

${ }^{70} \mathrm{It}$ is still customary that the minister who is responsible for the act attaches his signature next to the signature of the Führer on the act. By the countersignature he assumes responsibility toward the Führer. See Meissner-Kaisenberg, Staats- und Verwaltungsrecht im Dritten Reich 69 (r935).

${ }^{7}$ Ministers without portfolio are at present: The Deputy-Leader prior to the assassination of Röhm, also the Chief of Staff of the party army, and two other ministers, see Gesetz zur Sicherung der Einheit von Partei und Staat of December r, I933 (RGB. I, ror6). Several offices are directly under the control of the Reich Chancellor such as the Chief of the Press attached to the Reich government, and Commissioner for economic questions. The Führer maintains a sort of private government within the government which does not contribute to the smooth operation of the administrative machinery at the top.

72 Public Officials Act (Deutsches Beamtengesetz) of January 26, $x 937$ \& 56 ff., $x 84$ (RGB. I, 39), which repealed the Reich Minister Act of $1930 / 33$. The ministers are considered not as public officials in the proper sense, but as "holders of public office" (öffentliche Amtsträger), a rather inexplicable quasi-legal distinction apparently of some political importance.

At present the following ministries of the Reich exist: Foreign Office; Interior, for the 


\section{THE REICH PARLIAMENT (REICHSTAG)}

In the state under the leadership-principle the parliament ceases to be an independent organ of legislation. The Reichstag has become an instrument of dictatorship, destined in the main for serving as a mouthpiece for official declarations of policy on the part of the Führer. ${ }^{73}$ Although the Reichstag formally still holds concurrent legislative powers, it has been called upon to legislate only in a very few instances. No discussion has been demanded or permitted. After having listened, silently or clamorously, as the case may be, to the declarations of the government, the Reichstag has voted unanimously in military obedience to the command. ${ }^{74}$

In spite of its rubberstamp character, the Reichstag has been re-elected three times since r933. The first election occurred on March 5, I933; it was the last opportunity for various parties to vote. The second election, in the same year on November I2, served as a demonstration of national unity when Germany left the League of Nations, while incidentally enabling the government to get rid of the limitations of the Enabling Act. The third election, on March 29, I936, followed the breach of the Locarno Treaty by the remilitarization of the Rhineland. In the last two elections only the ticket of the single party, the National Socialists, was offered. All other parties had been outlawed previously by the act prohibiting the formation of new parties. ${ }^{75}$ The universal, equal, secret, and direct suffrage is nominally still in force. In conformity with the racial legislation Jews and Jewish "mixed offspring" (Mischlinge) were barred from voting at the elections on March 29, $1936 . .^{76}$ The suffrage is in abeyance for members of the armed forces. Under the system of proportional representation inherited from the Weimar Constitution a deputy for every 60,000 voters is provided. Not only has the number of registered voters increased con-

Reich and Prussia; Finance; Economic Life, for the Reich and Prussia; Labor, for the Reich and Prussia; Justice, for the Reich and Prussia; Reichswehr; Postmaster General; Communications, for the Reich and Prussia; Nutrition and Agriculture, for the Reich and Prussia; Public Enlightenment and Propaganda; Air; Science, Education, and Culture, for the Reich and Prussia; Forests, under the Reich Forest Master.

${ }^{73}$ The description by Dr. Frick, Reich Minister of the Interior, of the Reichstag as "the forum to which the Führer and Reich Chancellor brings the essential problems of the German nation's interior and foreign policy for discussion and decision" is hardly in conformity with the facts. Meissner-Kaisenberg, Staats- und Verwaltungsrecht im Dritten Reich 87 (I935).

${ }^{74}$ See the enumeration in note ${ }_{5} 5$ supra.

75 See Verordnung zur Sicherung der Staatsführung of July 7, I933 (RGB. I, 462) which cancelled the parliamentary mandates of the Social Democrats; Gesetz gegen die Neubildung von Partein of July I4, I933 (RGB. I, 478). According to this act the maintenance of the organization of a dissolved party or the formation of a new party is treason.

${ }^{76} \mathrm{Jews}$ who vote in spite of the law are punished by imprisonment, act of March 7, 1936 (RGB.I, 133). 
siderably by the return of the Saar, the vote of German residents abroad who were given free transportation, and the votes taken on board of German vessels abroad, but the political pressure of the party has in fact introduced compulsory voting and brought the percentage of votes cast to unprecedented heights. The number of deputies accordingly rose from 647 in the election of March I933 to 66I in the election of November, I933, and to 747 in the election of March, I936.

The monopoly accorded to the National Socialists was justified by virtue of the act guaranteeing the unity of party and state of December, $1933,{ }^{77}$ which proclaimed, in $\S \mathrm{I}$, ". . . . The National Socialist Party is the exponent of the German state idea and thus insolubly fused with the state." Since primaries were unfortunately conspicuous by their absence even under the Weimar Constitution the selection of party candidates is left exclusively to the discretion of the national manager of the party (Reichswahlleiter), the Minister of the Interior, in collaboration with the national party leaders and the district party leaders. The voter knew absolutely nothing about the composition of the electoral ticket and the sequence of candidates on the list because the official ballot paper, headed in every constituency by the Führer personally, contained only the names of ten prominent party leaders..$^{78}$ In violation of the electoral law the party leaders selected the actual deputies among about a thousand candidates only after the poll was taken. Thus the voter simply endorses a more or less anonymous list. Since it is technically impossible and politically dangerous to reject the official ticket, it is a travesty of democracy to link this type of "acclamation" with Article I of the constitution, so much referred to under National Socialism, "All powers of the state emanate from the people." Elections in the Third Reich are compulsory popular ratifications of party tickets in which the voter has no influence whatsoever. ${ }^{79}$

77 Gesetz zur Sicherung der Einheit von Partei und Staat of December I, I933 (RGB. I, I066).

${ }^{78}$ At the election in March, 1936 , cursory notes on the list of candidates were published only on the day preceding the elections.

79 Accordingly the deputies from the Saar were appointed from among the Saar voters by the Reich Chancellor. Moreover, the act amending the electoral law of July 3, I934 (RGB. I, 530) decreed by the cabinet immediately after the blood purge of June 30, 1934, by which also a considerable number of National Socialist deputies were "prevented from exercising the parliamentary mandate," by assassination or confinement to a concentration camp, reflects clearly the actual situation by providing that membership in the Reichstag is forfeited "by exclusion or resignation from the parliamentary party." By this legal device a party member who fell from favor was prevented from retaining his seat against the will of the party; see the statement in the Reichsanzeiger no. I55 (I934). By the same act the leader of the parliamentary party designates the successor of the eliminated deputy among the substitutes on the single party ticket presented at the last general election to the constituency. 
It is true that the Court of Inquiry into Elections, composed of members of the Reichstag and of the Supreme Cour ${ }^{80}$ has continued to function for both elections and plebiscites. Its findings, published after inordinate delay, have been valueless because no one dared to contest the legality of the election procedure. In addition, no impartial control of the election process itself was possible because only party members were admitted as members of the election board and as returning officers in the polling stations. The German elections are not to be evaluated in terms of democratic institutions. Organized under party pressure their result is a foregone conclusion. Only the percentage of votes cast in favor of the regime remains to be determined.

While the privileges and immunities of the deputies have not been formally repealed, they have become more or less meaningless since the removal of the constitutional guarantees against criminal proceedings ${ }^{8 x}$ because the principle of party allegiance and loyalty towards the Leader was substituted for the idea of free representation. It should be noted that the compensation for deputies of 600 marks monthly (\$240) continues although the Reichstag is convened not more than once or twice a year.

THE PLEBISCITE

Official spokesmen of the Third Reich untiringly claim for the regime the title of a "pure," "unadulterated," or even "ennobled" democracy. National Socialism is anti-parliamentarian though not anti-democratic. It is a truism that no government however authoritarian can maintain itself indefinitely against the will of the majority. The only problem was that of demonstrating urbi et orbi, the possibly unanimous endorsement of the governmental policy-not of the regime itself-by the nation. Since National Socialism excels in the art of creating and controlling mass-emotionalism, the restoration of the usus modernus plebiscitorum of the caesaristic type offered itself as a convenient device. ${ }^{82}$

In deviation from the Weimar Constitution the plebiscite of the Third Reich is not a legislative process although the Plebiscite Act of I933 states that "plebiscites may be taken also on statutes." ${ }_{3}$ The government may ask the people whether or not they consent to a measure intended by the

8o Weimar Constitution, Arts. 3I, I66.

8x Gesetz über die Immunität der Abgeordneten of June 23, I933 (RGB. I, 39I).

${ }^{82}$ See Loewenstein, Die Diktatur Napoleon des Ersten, 16 Zeitschrift für öffentliches Recht 635 (I936). Incidentally, the governmental system and technique of Napoleon reveal many striking parallels to the Nazi regime and modern dictatorships in general. See Loewenstein, The Dictatorship of Napoleon the First, 35 So. Atl. Q. 298 (1936).

${ }^{83}$ Gesetz über Volksabstimmung of July I4, I933, § I, alinea 2 (RGB. I, 479). 
government. The term, measure, includes any political act. Although the act prescribes that the plebiscite ought to precede the measure, thus far all three plebiscites were held after the step in question had been taken. An adverse vote was precluded automatically. The simple majority of the votes cast decides the issue even if the statute submitted to the vote amends the constitution.

The plebiscite taken on November I2, 1933, was to endorse the policy of the government in connection with the withdrawal from the League of Nations. ${ }^{8}{ }^{4}$ The second plebiscite involved the popular opinion on the Succession Act; ${ }^{85}$ and the third plebiscite was on the repudiation of the Locarno Treaty. ${ }^{86}$ The percentages of favorable votes for the three plebiscites were respectively $93 . \mathrm{r} \%, 84.2 \%$, and $97.8 \%$. The result of the second plebiscite would seem to indicate considerable disagreement as to the wisdom of conferring absolute power on the Führer.

A few remarks on the manipulation of the procedures of polling and counting in order to obtain the desired results must suffice. Clearly recognizing the dangers of the plebiscite which, when honestly applied, allows for demonstration of divergent opinion, the government took great care to minimize the eventual opposition. In the first place national issues were selected which would be endorsed even by opponents of the regime proper. Again the formulation of the question on the ballot paper was skilfully suggestive. The arrangements for polling and counting discouraged the

81 The ballot paper contained an elaborate statement of the arguments of the government; see proclamation of the government of the Reich of October I4, I933 (RGB. I, 730). Technically the procedure followed the former act on plebiscites of January 27, x92I (RGB. I, 79, as amended by the act of December 3I, rg23 (RGB. I924 I, I)). The official ballot paper was to be marked by "yes" or "no" on the blank circle space.

The result was published as follows:

\begin{tabular}{|c|c|}
\hline$\cdots$ & $45,176,713$ \\
\hline & \\
\hline ................ & \\
\hline & 2 , \\
\hline & \\
\hline & $\begin{array}{l}45,590,402 \\
43,569,695 \\
38,394,471\end{array}$ \\
\hline d J but & $\begin{array}{r}4,301,429 \\
873,787 \\
1,980,607\end{array}$ \\
\hline
\end{tabular}

${ }^{86}$ The same marking technique was applied as in the preceding plebiscite. The following figures were made public:

$$
\begin{aligned}
& \text { Total number of registered voters........ } 45,428,64 \mathrm{I} \\
& \text { Total votes cast................... 44,952,476 } \\
& \text { Yes............................ 44,409,522 } \\
& \text { No or invalidated ballot papers.......... } \quad 542,954 \\
& \text { Abstentions from voting............... } 476,165
\end{aligned}
$$


opposition. In particular, the arbitrary interpretation of invalidated ballotpapers, ${ }^{87}$ and frequently open violation of the secrecy of the vote helped to swell the percentage of popular approval even if one discounts the reasonable doubts raised concerning the truth of the officially published figures. Needless to say that the pressure of the propaganda machine geared to its highest pitch succeeded in stampeding public opinion. By the control of the party the vote was in fact compulsory. Nevertheless at least the majority of abstentions should be taken as expression of opposition. It seems that the extraordinarily high percentages of votes in favor of the government aroused suspicion even among the docile Germans and apparently a strong minority of voters was not mistaken in appraising as merely a hollow echo a plebiscite which was stripped entirely of its democratic ingredients.

THE LEGISLATIVE PROCESS

A statute passed in the Third Reich is no longer the untrammelled expression of popular will manifested by freely chosen representatives or by general popular votes. It is rather the command of the leader under the dogmatic assumption that the Führer's wisdom monopolizes and anticipates the popular will. Lawyers unbiased by the mystical rigamarole are unable to express this magic or charismatic doctrine in understandable legal terms.

In practice the normal type of legislation is the government decree (Regierungsgesetz) which is indiscriminately applied to all kinds of legislative acts whether they establish general and permanent rules of law or regulate only particular cases of limited application. The customary distinction between formal statutory law, subject to parliamentay participation even if the content is no general rule but a political measure, and material statutory law, meaning the establishment of general rules of law which are not necessarily subject to parliamentary participation is abandoned while the traditional formalities of publication (Verkündung) and promulgation (Ausfertigung) are still observed. Every government decree is signed by the Chancellor and countersigned by the minister to whose departmental functions the act materially belongs (federführender Reichs-

${ }^{87}$ In the plebiscite taken on the Locarno Treaty the official ballot paper contained no space for a negative vote, but only for "yes." It was generally presumed by the voters that unmarked ballot papers would be counted as "no" since the official instructions had deliberately avoided any indication of how to reject the proposal. Such papers were, however, counted as affirmative. The number of such papers left blank was never published. Foreign reporters observing the procedure in the polling stations testified to the very considerable number of such manifestations of "no." 
minister). Decrees of particular importance are signed by the entire cabinet. The legislative jurisdiction of the government is exercised regardless both of the powers re-delegated to the Länder and of the nominally preserved powers of the Reichstag. It has been mentioned already that the distinction between ordinary law and organic law is completely obliterated because the Enabling Act and the Reconstruction Act conferred upon the Reich government the amending power without limitations. The legislative power of the cabinet also embraces the budget and the money borrowing function. ${ }^{88}$ It may be added that the third method of legislation provided for by the Weimar Constitution, namely a referendum inaugurated by popular initiative, has become obsolete because any combination of voters for political purposes not sponsored by the government is punishable as unlawful organization of a political party. Summing up the present situation, then, it is obvious that instead of the separation of legislative and executive functions deemed essential for constitutional government there is a complete concentration of powers in the hands of the government. Concomitantly the guarantees of individual or subjective rights of the individual towards the state are a matter of the liberalistic past and justly so because psychologically the separation of powers implies the recognition of individual or subjective rights which are no longer compatible with the totalitarian state.

\section{THE ORDINANCE MAKING POWER}

The technique of legislation has undergone a complete change. The statute is no longer immediately applicable in practice, but indicates only the general policy of the bill in very broad and not infrequently flamboyant terms while the detailed regulation and practical application are left to the ordinance making power. Hence, the unprecedented growth of ordinances, both in volume and importance. The line of demarcation between legislative and ordinance making powers is more or less obliterated. In consequence thereof the distinction between "statutory ordinances," establishing general rules of law under explicit delegation by the statute,

\footnotetext{
${ }^{88}$ Weimar Constitution, Arts. $85^{-2}, 87$. A special provision covering these powers was inserted in the Enabling Act of 1933 for solving a problem of constitutional law hotly debated prior to the seizure of power by the National Socialists. Particularly the Board of Control of the Public Indebtedness (Reichsschuldenverwaltung) had maintained that for the enactment of the budget and for credit transactions a formal act of the Reichstag was needed and that an ordinance of the Reich President on the basis of Art. 48 was insufficient. On the important constitutional problem of whether certain articles of the Constitution enjoyed "immunity from dictatorial interference" (dikaturfest), see Anschütz, Die Verfassung des Deutschen Reichs 287, 44I (I933); see also the act of May 5, I932 (RGB. I, I9I).
} 
the limits of which are to be carefully observed, and mere "administrative instructions," has become meaningless because both emanate from the same source, namely the government decree. It would be erroneous to assume that thereby the hierarchy of the sources of the law was simplified. On the contrary the wide use of the ordinance making power by numerous delegated and overlapping authorities is confusing, and the lack of certainty in jurisdiction makes business life in Germany increasingly diffcult.

In view of the fact that during the initial period of the "national revolution" many measures were taken, particularly by the Länder governments, for which no juridical basis existed, a sweeping Indemnity Act was necessary. ${ }^{89}$ This act legalizing revolutionary lawlessness may be likened systematically to the famous act "concerning the measures of self-defence of the state" of July, I934, a unique piece of self-justification which "normalized" the crude illegalities committed by Hitler himself and his associates in the blood purge of June 30 , $1934 . .^{90}$

All powers of issuing ordinances are at present combined in the person of the Führer and Chancellor who wields the old powers of the President in addition to the new powers as leader of the National Socialist Party. ${ }^{9 x}$ Another very common type of ordinance is that on the basis of a statute which usually contains a delegation clause to the effect that executory ordinances may be issued by the cabinet as a whole or by an individual minister. ${ }^{92}$ In general the limits of the ordinance are only those indicated by the general policy of the statute itself, a fact which makes the control of the ordinance-making power by the courts-occasionally remembered by National Socialist jurisprudence-wholly illusory. If ever a court were bold enough to invalidate an administrative act because ultra vires of the

${ }^{89}$ Gesetz über Rechtmässigkeit von Verordnungen und Verwaltungsakten of July 3, r934, $\$_{2}$ (RGB. I, 530).

90 Gesetz über Massnahmen der Staatsnotwehr of July 3, I934 (RGB. I, 529). For details see Loewenstein, Law in the Third Reich, 45 Yale L. J. 779, 8ro ff. (1936).

${ }_{9 r}$ Gesetz über die Einheit von Partei und Staat of December I, I933 $\$ 8$ (RGB. I, I060); frequently the ordinance-making power is delegated to the Deputy-Leader of the party.

92 General and unlimited powers to make ordinances are delegated to the Minister of the Interior by the Reconstruction Act $\S 5$; to the Minister of Justice by the Unification of the Administration of Justice Act (Gesetz zur Überleitung der Rechtspflege auf das Reich) of February I6, I934 (RGB. I, 9I); to the Prussian Minister President Göring in connection with the Four Years Plan of 1936 . The Verordnung zur Durchführung des Vier-Jahres-Plans of October I8, I936 (RGB. I, 887) declares laconically: "I entrust the execution of the Four Years Plan to the Minister President Göring. He has the power to issue general orders and administrative instructions." This important plan which cuts deeply into the economic structure of private capitalism is not even disguised as a formal act. 
delegation, a new ordinance could make it valid ex tunc. Nothing illustrates better the legalized arbitrariness which governs legal life in the Third Reich. ${ }^{93}$

JUDICIAL POWER AND ADMINISTRATION OF JUSTICE

For obvious reasons no room is left for judicial review of statutes. No constitutional charter exists by which the legality of the individual legislative act can be measured. The law as a command of the Leader does not brook the control involved in judicial review. Any law emanating from the government is unchallengeable both formally and substantially. The same is true of the few acts passed by the Reichstag. The only remaining test of validity is found in the principle of lex posterior derogat legi priori, which guarantees once and for all the legality of the subsequent statute as against a preceding one and the constitution itself.

This legal situation could not fail to affect fundamentally the position of the judiciary branch within the state. No longer are the judicial functions well protected against the combined executive and legislative powers. Independence of judicial administration is superseded by political subservience to the law as the command of the Leader. The decision of the magistrate or court is to serve exclusively the political will of the state as expressed in the Leader's command. ${ }^{94}$ Since the law and the discretionary will of the Führer are identical, the fundamental tenet of Article ro2 of the constitution: "Judges are subject only to the law" is not formally affected because the judge in obeying the law obeys the Leader's command. Yet the position of the judiciary is deeply uprooted since the independence of judges and the life tenure of office has been virtually abrogated by the new regulations concerning public servants. ${ }^{95}$ Thus the postulate of justice according to law is fulfilled to the letter when it is realized that the law is the will of one human man alone and that justice is no longer shaped in conformity with the ethical standards of public opinion, because public opinion is molded by the few at the top.

The most incisive transformation of the organization of the courts and judicial administration consists in the transfer of judicial sovereignty (Justizhoheit) from the Länder to the Reich. In the place of the former

${ }_{93}$ See in this connection, the act of December 13 , I934 withdrawing all lawsuits involving the legality of revolutionary "actions" on the part of public officials or private persons from the ordinary courts and transferring them to the Minister of the Interior who settles them without appeal. Gesetz über den Ausgleich bürgerlicher Rechtsstreitigkeiten of December 13, I934 (RGB. I, I 235); see Loewenstein, Law in the Third Reich, 45 Yale L. J. 779, 807 (I936).

94 Meissner-Kaisenberg, Staats- und Verwaltungsrecht im Dritten Reich 282 (I935).

95 See p. 566 infra. 
Departments of Justice of the various Länder, at present delegates of the Reich-Ministry of Justice hold office in the capitals of the former Länder. All judicial officers are officials of the Reich and no longer of the Länder..$^{96}$

In the ordinary jurisdiction of the courts surprisingly little was changed. On the other hand not a few special courts, mainly for protection of the regime against its enemies, have been established in which curtailing of the customary guarantees of due process is characteristic. ${ }^{97}$ In addition, the new feudalistic tendencies of creating separate "estates" and guilds of the various professions and crafts are responsible for the emergence of manifold professional and "honor" courts..$^{8}$ The most serious competition of the ordinary courts, however, arises in the party courts which create a separate law for party members. ${ }^{99}$

\section{CIVIL SERVICE}

The politically neutral civil service, together with the army, was the pillar of the German state although under the Empire it was to some extent an instrument of the ruling classes and at least in its higher ranks, recruited its members largely from among them. The German civil service was justly renowned for its administrative efficiency on the basis of special training and general examinations. The Republic was intent upon maintaining the tradition of political neutrality and devotion to the office among the public officials. The number of men gaining access to the service by means of political patronage was not excessive. National Socialism uprooting the tradition deliberately converted the civil service into an instrument of political domination. Unconditional defense of the political aims of the regime now takes precedence over objective administrative efficiency. The German official of today swears loyalty no longer to the abstract notion of the state or the fulfilment of his duties, but he pledges personal allegiance and unreserved obedience to the person of the Führer himself. No longer is technical qualification for the office the exclusive condition of appointment, but proof of political reliability is equally and in

${ }^{96}$ Compare the gradual development in the following statutes: I., 2., and 3. Gesetz zur Utberleitung der Rechtspflege auf des Reich of February I6, of December 5, x934, and of January 24, I935 (RGB. (I934) I, 9r, r2I4; id. (I935) I, 68).

97 The most notorious among them is the Peoples Court (Volksgerichtshof), established by the act of April 24, I933 art. III, \& I-5 (RGB. I, 345); see Loewenstein, Law in the Third Reich, 45 Yale L. J. 779, 808 (1936); by the act of April I4, I936 (RGB. I, 369), these tribunals of the star chamber type were transformed into ordinary courts in the terms of the Judicature Act. The special courts (Sondergerichte) were established by Ordinance of March 2I, 1933 (RGB. I, I36).

${ }_{98}$ See Loewenstein, Law in the Third Reich, 45 Yale L. J. 779, 808, n. 104 (1936).

99 Id. at 809 . 
practice even more important. ${ }^{x 00}$ The new Public Officials Act of January 26, I937, declares in its first sentence: "The German public official executes the will of the state and of the National Socialist Party." The legal pretext of the identity of state and party serves to cover the fact that the once politically neutral civil service has officially surrendered to the patronage of the party to such an extent that at present no appointment, except for minor officials, is possible unless the applicant is a tested member of the party and has undergone special training in the party doctrine. The older officials are rapidly being replaced by party members. The membership card as technical qualification for office is responsible, according to reports of unbiased observers, for the decay of administrative efficiency in almost all walks of public life. Space again forbids any detailed description of the status of public officials in the Third Reich. It should be noted, however, that persons of non-German blood and those married to a partner of non-German blood are no longer eligible for office. ${ }^{\text {.ox }}$ Furthermore, vested rights of the officials which have contributed so much both under the Empire and the Republic to the prestige and security of the civil service are no longer recognized. Even the new Public Officials Act of $\mathrm{r} 937$ which takes great pains to return at least on paper to the traditional concepts of the civil service contains so many political reservations and pitfalls that security of tenure continues to depend on political conformity. On the other hand the new act benefits from the relentless process of weeding out the politically unreliable public officials during the last years. Since judges and academic teachers are equally subjected to the requirements of civil service it is obvious that political reliability of no category of officials escapes a continuous scrutiny. Thus one of the main objectives in stabilizing the regime is reached in that public officials are made political tools. It should be added that the number of administrative offices and beneficiaries of party and state have inordinately increased under the totalitarian Third Reich.

PARTY AND STATE

After the establishment of the leadership principle and the attendant abolition of the separation of powers, perhaps the most momentous constitutional development of the Third Reich is the fusion between party and state, achieved legally by the technique of the single party state. The

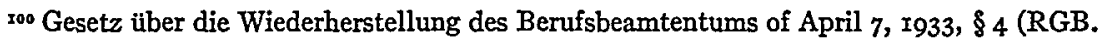
I, I75); Gesetz zur Anderung von Vorschriften auf dem Gebiet des allgemeinen Beamten-, des Besoldungs- und des Versorgungswesens of June 30, r933, § 3 (RGB. I, 433), now consolidated in the Public Officials Act of January 26, I937 (RGB. I, 39).

ror Act of June 30, I933, § ra alinea 3 (RGB. I, 433); Public Officials Act of I937, § 25. 
rise of the National Socialist movement from a small political group to the strongest party in the elections of July, I932, is too well known to be repeated here. The National Socialists emerged from the elections of March, I933, with the ambition of being the exclusive link between state and nation, fulfilling the trichotonomous concept of the National Socialist doctrine. This ambition was realized in the dissolution and prohibition of all other political parties, accomplished immediately after the rupture of the coalition cabinet. Maintenance of a dissolved party or formation of a new party became treason. ${ }^{102}$ Subsequently the Act on the Unity of Party and State of December $\mathrm{r}, \mathrm{I} 933{ }^{\mathrm{x}}{ }^{\mathrm{O} 3}$ established by force of law the monopoly of the National Socialist Party within the state. The party was declared a public corporation and given far-reaching privileges of exemption from the general laws. The unofficial special courts for party members were legally recognized as judicial agencies of the state; the ordinary authorities of the state were bound to assist party officials in the exercise of their functions. A special Deputy Leader in party matters was appointed who is an ex-officio member of the cabinet. The entire area of the Reich was covered by the most elaborate administrative machinery of the party, divided into provinces (Gau), districts (Kreis) and local units (Ortsgruppe). In addition to the party proper and its affiliated official organizations such as SA (Storm Troopers), SS (Special Guards), National Socialist Women's Organization and the all encompassing Hitler-Youth, the party touches with its countless professional and social groups of vast dimensions all layers of the population. ${ }^{\mathrm{x} 4}$ Perhaps never before has the German genius of organization scored a higher triumph. Those still outside of the party organizations or of the party controlled professional estates or guilds are miserable outcasts. The party and its affiliated organizations enjoy the special protection of the law. ${ }^{\text {105 }}$

The most efficient method, however, of permeating the entire fabric of the state with national social spirit is that of co-ordinating party officials with the administrative offices of the state. The party controls and influences the administrative authorities by special party superintendents or agents (Amtswalter) who not only supervise the ordinary officials, but

${ }^{102}$ Gesetz über die Neubilding politischer Parteien of July I4, I933 (RGB. I, 479).

${ }^{303}$ Gesetz über die Einheit von Partei und Staat of December I, I933 (RGB. I, ror6).

${ }^{304}$ For example, the German Labor Front, The Federation of National Socialist German Lawyers, and the Reich Federation of Public Officials.

ros Gesetz gegen heimtückische Angriffe auf Partei und Staat und zum Schutze der Parteiuniformen of December 28, I934 (RGB. I, I269) which punishes "utterances likely to undermine the confidence of the people in the political leadership." Manifestations of party symbolism such as uniforms, badges, swastikas, and flags are equally protected. 
also perform directly administrative functions. ${ }^{\text {106 }}$ While thus state and party are linked together it is unavoidable that the interference of the party in the administration results in friction and a waste of energy which render the administrative system of the Third Reich both complicated and monstrously extravagant. Perhaps the German genius for organization overreaches itself. On the other hand, the powers of the lower party bureaucracy are in actual practice beyond control. The result is a good deal of divergence in administration which the central party authorities are frequently unable to rectify.

Similarly the party invaded the dominion of communal government. The Municipal Government Act of I935, another organic statute of the Third Reich, ${ }^{107}$ evidently attempts to square the circle by proclaiming that "municipal administration is to be self government while at the same time establishing conformity with the political aims of the government (Staatsführung)." The democratic-parliamentarian form of municipal government is abolished. The mayor (Bürgermeister) and associates of the mayor (Beigeordnete) are appointed by the government of the Land. ${ }^{108}$ For special interests of the party the "delegate commissioner of the $\mathrm{Na}$ tional Socialist Party" is appointed by the Deputy-Leader of the party. ${ }^{109}$ The delegate-commissioner's consent is necessary for appointment and dismissal of the mayor, the associates of the mayor, and the town councilors $^{\mathrm{IrO}}$ and the enactment of the municipal charter. ${ }^{\mathrm{IrI}}$ Needless to say the leadership principle also dominates the municipal sphere and that no trace of popular elections is left. It should be noted, however, that the old pattern of official honesty and efficiency has been less revolutionized in municipal administration than in the administration of the state itself because the power of public opinion, even if it is silent, is more effective in the neighborly atmosphere.

${ }^{106}$ The duplication of frequently overlapping functions is revealed for example in the fact that the Minister of Nutrition also holds personally the office of the National Leader of the German Farmers (Reichsbauernführer) and he is simultaneously Chief of the Farm Board of the party. In the highest administrative units the identity of state and party is further evidenced in that the leaders of the provinces (Gauleiter) hold the office of Reich Regent or, in Prussia, of Provincial Governor (Oberpräsident).

so7 Deutsche Gemeindeordnung of January 30, 1935, \& 2 (RGB. I, 49).

${ }^{108}$ Id. at \& alinea 2.

${ }^{109} \mathrm{Id}$. at $\$ \mathrm{II8}$. The ordinance of the Deputy Leader of March 26, r935 (RGB. I, 470) decrees that the "delegate-commissioners" of the party are to be appointed by the provincial leader of the party (Gauleiter). Delegates are usually the district managers of the party.

Iro $I d$. at $\S \S 4 \mathrm{I}, 45,5 \mathrm{r}, 54$.

III Id. at $\S 33$. 


\section{CITIZENSHIP}

Citizenship in the Third Reich has been fundamentally affected by the suppression of the statehood of the Länder, by the fight against the opposition-officially named "enemies of the state" and last by the racial legislation.

When sovereignty passed from the Länder to the Reich no room was left for citizenship in the individual Land. At present only uniform nationality as citizens of the Reich exists. ${ }^{\text {Ir2 }}$ The Länder authorities handle matters concerning nationality in the name of and by delegation from the Reich. Naturalization is dependent on the consent of the Minister of Interior.

Naturalization granted between November 9, I9I8, and January 30 , x933, may be revoked if the citizen is deemed "undesirable," mainly for political or racial reasons. ${ }^{\mathrm{xr} 3}$ In addition, German nationals residing abroad may be deprived of citizenship if their conduct is deemed detrimental to German interests or if they refuse to return on request. At the same time confiscation of the property of such persons is permissible. On the basis of these provisions a considerable number of German nationals have been deprived of their citizenship, particularly non-Aryans naturalized after I 9 I8, and political dissenters. On the other hand, many foreigners who have served the interests of the party, especially refugees and sympathizers from Austria and Czechoslovakia have been rewarded with citizenship..$^{\text {II }}$

The Reich Citizenship Act of $1935,{ }^{\text {,r5 }}$ one of the "Nüremberg laws" and again an organic statute of the Third Reich, introduced the subtle distinction between citizens (Reichsbürger) and nationals (Staatsangehörige). Only a national of "German or racially similar blood who proves by his behavior that he is willing and capable of serving loyally the German national state" is a citizen. ${ }^{\text {II }}$ Citizenship is acquired by getting the formal citizenship-certificate (Reichsbürger-Brief). Only citizens are qualified to exercise fully all political rights. On the other hand, German subjects or nationals are described as those "who being members of the protective

${ }_{12}$ This internationally as well as nationally important innovation is hidden in the Ordinance of February 5, I934 (RGB. I, 85).

${ }^{1 \times 3}$ Gesetz über den Widerruf von Einbürgerungen und Aberkennung der Staatsangehörigkeit of July I4, I933, \& I (RGB. I, 480).

${ }^{{ }_{4} 4}$ Several persons convicted of high treason by Czechoslovakian courts were "elected". to the Reichstag in I936. A special act of February 27, I936 (RGB. I, I27) admitted naturalized foreigners even to the career of a judge although they need not comply with the internal requirement of training and admission.

Irs Reichsbürgergesetz of September 15, I935 (RGB. I, Ir46).

${ }^{116} I d$. at $\$ 2$. 
union of the German Reich are accordingly under special obligations towards the same." ${ }^{\text {II7 }}$ By this act, all Jews are deprived of citizenship. ${ }^{\text {Ir8 }}$

As would be expected the distinction between citizens and nationals serves exclusively the purpose of anti-semitic discrimination. Evidently it was impossible to apply the vague tèrminology of the statute to any special category of persons except non-Aryans. Hence, all persons are citizens at present who possessed the right to vote when the act was passed. ${ }^{119}$ To treat Germans, other than Jews, as second-rate citizens if such a division for political reasons were feasible would gravely have endangered the pretended unity of the German nation and widened the existing cleavage between party members and ordinary citizens. Thus the much advertised distinction between citizens and nationals is no more than another stroke of legalized anti-semitism.

IV. CONCLUSIONS

In appraising the system of constitutional law which National Socialism has created during the first four years of powers, the foreign observer is naturally influenced by his concepts of legal values and knowledge of history. At this stage, the verdict of history on the Third Reich can hardly be anticipated. Perhaps National Socialism is to be credited with having inaugurated a new type of government. Perhaps, and this is more likely, the ultimate purposes of nationalism, a new social stratification and racial eugenics, will appear ephemeral aims, not deserving the fanatical energy expended on them, when measured by the attendant loss of permanent values of freedom, human dignity and personal self-realization. At any rate, the speculative nature of such possible evaluations may not preclude the constitutional lawyer from venturing some general conclusions on his own field.

Even without a fixed fundamental charter the structural organization of the Third Reich presents itself as an all-encompassing and jointless system of constitutional law which is admirably suited to serving the totalitarian ambitions of the regime. Although artificially created and forcefully superimposed, it incorporates many of the inherent traits of a nation whose legal tradition has been strangely affected by such mutually exclusive concepts as romanticism and positivism. Reverence for the omnipotence of the super-personal state and subservience to authority

${ }^{127} I d$. at $\$ \mathrm{I}$.

"18 For the legal definition of the term "Jew" see Executory Ordinance of November 14, I935, \& 5 (RGB. I, I333). On the very complicated "Nüremberg laws" see Loewenstein, Law in the Third Reich, 45 Yale L. J. 779, 796 (I936).

ng See, however, note 76 supra. 
are so deeply engraved in the German character that the contradiction between "Leader's command" and the majesty of objective law is readily accepted. The brief interlude of the Republic between two authoritarian regimes has evidently left no traces on the consciousness of the public. Loss of liberty is compensated for by the gratifying interest of party and state in the well-being of the humblest citizen. In addition, it must be granted that the constitutional technique of the regime has thus far been serviceable in the attainment of the more obvious aims such as practical anti-semitism, restoration of the military traditions, and transfer of the vast emoluments of party and state to the new social stratum of the party bureaucracy recruited mainly from the dispossessed middle classes. Furthermore, the regime travels fast on the road to a more remote destination, namely, to where private capitalism and state capitalism converge. Here perhaps only spade work is done for the heir apparent, state socialism.

Yet the observer cannot but notice some fissures in the seemingly solid façade of the Third Reich. It is difficult to see how in the long run the radical elimination of the intermediary agencies between the citizens and the central government will satisfy the inherent needs of modern states for administrative decentralization while still preserving political unity. The connecting links supplied by Länder, which were essentially cultural units, are not missed, at least for the time being, because the party fills the need. But it is open to doubt whether the party, admirably organized as it is, will in the last analysis respond to the intellectual habits of a nation whose national gregariousness has not prevented social multiformity. Whenever the single party disintegrates or disappears, the inordinate centralization may prove detrimental to political unity.

Another danger lies in the development of the party itself. Unlike the state in the development of Russian bolshevism, the state in Germany was compelled by the marriage to the party to surrender many of its powers. In the deliberate subordination of the civil service to the party, another pillar of the constitutional edifice has been hollowed out ready to fall whenever the party disintegrates or disappears. Through the totalitarian tasks of the state the party has increased numerically to such an extent that it is no longer a revolutionary élite. On the contrary it has become a heterogeneous mass of men materially interested in the maintenance of the spoils. Industrialists now wear the party badge as well as the "old fighters." Since influence in the state is obtainable only through the party, opportunists outnumber the genuine loyalists. What little of ideological ingredients the party contained when conquering the state as a revolu- 
tionary minority has undergone the seductions of four years of undisputed power. Conflicting interests within the pretended homogeneity are only temporarily compromised without being definitely conciliated. Revolutionary purges too easily become dangerously repetitious. Since the identity of party and state is a fact of which National Socialism is proud, this imperfect integration of the unwieldy elements cannot but ultimately affect the political and administrative apparatus of the state itself.

What appears at the present moment as the strength of the system, namely that it rests on the rock-bed of a mass party may easily become its weakness in spite or because of the ever-increasing numbers of party beneficiaries. In addition, the artificial division of the nation into neofeudalistic groups, estates, and guilds is not entirely devoid of danger. Thus far this efficient device for totalitarian control of economic and intellectual life has not outgrown its original purpose.

Another weakness of the system is visible at the top. Even a genius of Napoleonic caliber is unable to cope with the technological demands of the modern state. In spite of rather hectic efforts to train future "leaders," the Third Reich lacks creativeness in renewing the leadership personnel whose function is to transform the political impulses of the Führer into administrative realities. To maintain the former associates in the key positions of the state for the sake of their political merits in the past has not promoted administrative efficiency. The Führer has been all the more unwilling to overcome this danger of petrification inherent in all dictatorships because in his code of ethics loyalty stands for professional knowledge and political reliability for expert advice. No machinery exists for changing the uppermost layer. As a selective process the party by its very nature is decidedly inferior to parliament or the civil service. The leadership hierarchy, with its mystical notions of infallibility discourages rational selection.

Finally there is a tangible disadvantage in the constitutional structure of the Third Reich. The leadership principle operates perfectly from the top down to the base of the social pyramid, but no mechanism exists which carries the opinions and reactions of the masses up to the apex of leadership. While the leaders succeed in moulding the masses by the mechanism of domination they are impervious to influences moving from below to the summit. The leadership principle itself causes the complete isolation of the leaders from those whom they lead. There is no such thing as "leadership-democracy" as proclaimed by National Socialism. Consequently during these four years the regime has become rigid and unpliant. The emotional enthusiasm of the masses which is so masterfully 
handled by the technicians in rhetoric of the regime strikes the observer frequently as unreal and ghostly.

But even the density and accumulation of such ominous foreshadowings indicate no immediate consequences for the stability of the regime. On the contrary, the congruity between the methods of domination and the national character may, in the long run, lead to a normalization of the regime of which there are at present no visible signs. The essential justification of any political system is that of reflecting the norm of the national traditions and of maintaining the equilibrium of social forces. Dictatorships are usually incapable of normalization. National Socialism in its present aspect is certainly the most thoroughgoing organization of social life, the most omnipotent leviathan, in Hobbes' phrase, known in modern history. Paradoxically it is the most notable feature of the Third Reich that it has succeeded in organizing arbitrariness in the form of law. The German nation, by the mystical alchemy of its spirit adores organization and efficiency, but it is doubtful whether organization for its own sake and as an end in itself without the vitalization of absolute values will be able to withstand the serious strain which the future holds in store. 